\title{
Synthesis of novel epibatidine-related derivatives through 1,3- dipolar cycloaddition of pyridinenitrile oxides
}

\author{
Clelia Dallanoce,* Paola Bazza, Giovanni Grazioso, Marco De Amici, and Carlo De Micheli \\ Istituto di Chimica Farmaceutica e Tossicologica, Università degli Studi di Milano, \\ Viale Abruzzi 42, 20131 Milano, Italy \\ E-mail: clelia.dallanoce@unimi.it
}

\begin{abstract}
The $\Delta^{2}$-isoxazoline derivatives $3 \mathbf{a}-\mathbf{c}$ and $\mathbf{4 a - c}$, structurally related to epibatidine, and the simplified analogues 5a-c were synthesized by means of a 1,3-dipolar cycloaddition of regioisomeric pyridinenitrile oxides to suitable dipolarophiles. Target compounds were assayed at $\alpha 4 \beta 2$ and $\alpha 7$ neuronal acetylcholine receptor (nAChR) subtypes. Competition binding experiments at $\alpha 4 \beta 2 \mathrm{nAChRs}$ showed an overall significant reduction in affinity for the compounds under study in comparison to the reference radioligand $\left[{ }^{3} \mathrm{H}\right]$-epibatidine. On the other hand, compounds $\mathbf{3 b}$, 3c, and $\mathbf{4 b}$ exhibited a noticeable affinity for the $\alpha \mathbf{7}$ receptors and $\mathbf{3 c}$ showed also a slight degree of $\alpha 7$ over $\alpha 4 \beta 2$ selectivity.
\end{abstract}

Keywords: Synthesis, 1,3-dipolar cycloaddition, nitrile oxides, epibatidine analogues, neuronal nicotinic receptors, binding affinity

\section{Introduction}

The nicotinic acetylcholine receptors (nAChRs) are a superfamily of ligand-gated ion channels, which also includes $\mathrm{GABA}_{\mathrm{A}, \mathrm{C}}$, glycine, and 5- $\mathrm{HT}_{3}$ receptors. ${ }^{1,2}$ Neuronal nAChRs are widely distributed in the human brain, where they are frequently associated with modulatory events and, to a lesser extent, mediate synaptic transmission. ${ }^{3}$ Their molecular structure is characterized by pentameric combinations of homologous, genetically distinct $\alpha$ and $\beta$ subunits $(\alpha 2-\alpha 10$ and $\beta 2$ $\beta 4$ ), whose differential association confers specific structural and functional properties to the resulting receptor subtypes. ${ }^{4-7}$ The different neuronal nAChRs, which are stimulated by $(S)$ nicotine 1 (Figure 1) or by synthetic compounds, ${ }^{8,9}$ are involved in a number of functional processes such as cognition, learning and memory, cerebral blood flow and metabolism, as well as in an array of pathological conditions such as Alzheimer's and Parkinson's diseases, schizophrenia, epilepsy, Tourette's syndrome, anxiety, depression and nicotine addiction. ${ }^{6,10-12}$ The role played by neuronal nAChRs in a variety of pathological states stimulated the 
development of novel and potentially useful therapeutic agents promoted by the identification of suitable pharmacophore models. ${ }^{13-17}$ Research efforts have mainly concerned ligands selectively acting at the $\alpha 4 \beta 2$ and $\alpha 7$ receptor subtypes, ${ }^{18}$ the two major populations of nAChRs found in the brain.

The discovery of epibatidine 2 (Figure 1), an alkaloidal toxin isolated from the skin of the Ecuadorian poisonous frog Epipedobates tricolor, ${ }^{19}$ has renewed the interest in targeting nAChRs for analgesia. ${ }^{20-22}$ Epibatidine has potent $\mathrm{nAChR}$ mediated analgesic activity since it agonizes neuronal $\alpha 4 \beta 2$ subtypes with a binding affinity that is 30 times higher than that of nicotine. ${ }^{23}$ The main obstacle to the clinical use of epibatidine as an analgesic drug is its very narrow therapeutic index, which has been attributed to the lack of any marked selectivity for a single nAChR subtype. ${ }^{24-26}$ Nevertheless, epibatidine is a reference compound for all investigations on nAChRs and a model structure for the design of novel, high affinity and subtype-selective nAChR ligands. Epibatidine-related derivatives have been synthesized by varying the heteroaryl moiety, ${ }^{27-29}$ or functionalizing and expanding the alicyclic skeleton, ${ }^{30-33}$ or modifying the substituent and/or the position of the epimino nitrogen atom. ${ }^{34,35}$

In the light of the above discussed evidences we designed a group of novel compounds in which the two structural elements featuring epibatidine (i.e. the 7-azabicyclo[2.2.1] heptane system and the pyridine ring) were distanced by the insertion of a $\Delta^{2}$-isoxazoline moiety, either spiro-condensed (derivatives 3a-c) or fused (derivatives 4a-c) with the azanorbornane core (Figure 1). In addition, we synthesized and tested compounds 5a-c (Figure 1), in which the ethylene bridge of the bicyclic system of 4a-c was removed. The aim of this study was to investigate the effect of the variation of both the epimino- $N /$ pyridine- $N$ distance and the conformational profile on the affinity/selectivity for the nAChR subtypes. Since the chlorine atom located on the pyridine ring makes a minor contribution to the affinity of epibatidine ${ }^{36}$ we decided to synthesize the unsubstituted pyridinyl regioisomers only. Moreover, the novel chiral derivatives 3a-c and 4a-c were prepared as racemates by taking into account the similar receptor binding efficiencies of the epibatidine enantiomers. ${ }^{28,37,38}$ This paper reports the synthesis of compounds 3-5 and the evaluation of their binding affinity at $\alpha 4 \beta 2$ and $\alpha 7 \mathrm{nAChR}$ subtypes. The present results represent a further application of the cycloaddition strategy to the synthesis of biologically active heterocycles, which has characterized our research in the recent years with a focus on chiral $\Delta^{2}$-isoxazoline derivatives selectively acting at the different glutamic acid receptors and transporters. ${ }^{39-42}$ 


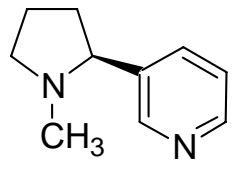

1

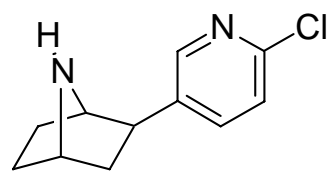

2

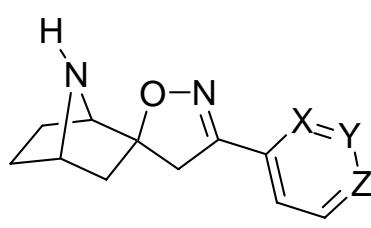

3a: $X=\mathrm{N}, Y=\mathrm{CH}, \mathrm{Z}=\mathrm{CH}$

3b: $X=\mathrm{CH}, Y=\mathrm{N}, Z=\mathrm{CH}$

3c: $X=\mathrm{CH}, Y=\mathrm{CH}, Z=N$

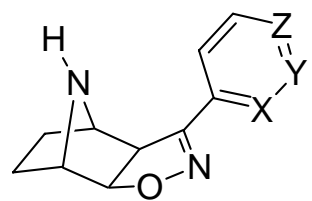

4a: $X=\mathrm{N}, Y=\mathrm{CH}, \mathrm{Z}=\mathrm{CH}$

4b: $X=\mathrm{CH}, Y=\mathrm{N}, \mathrm{Z}=\mathrm{CH}$

4c: $X=\mathrm{CH}, Y=\mathrm{CH}, Z=N$

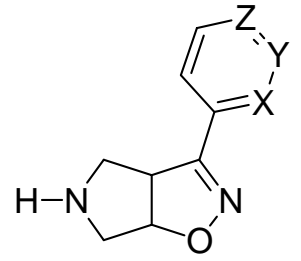

5a: $X=\mathrm{N}, Y=\mathrm{CH}, Z=\mathrm{CH}$

5b: $X=\mathrm{CH}, Y=\mathrm{N}, \mathrm{Z}=\mathrm{CH}$

5c: $X=\mathrm{CH}, Y=\mathrm{CH}, Z=\mathrm{N}$

Figure 1. Structure of model and target ligands for neuronal nAChR subtypes.

\section{Results and Discussion}

The synthetic approach to the desired final compounds is outlined in Scheme 1. Intermediate $\Delta^{2}$ isoxazolines 9a-c, 11a-c, and 13a-c were prepared by a 1,3-dipolar cycloaddition involving the appropriate pyridinenitrile oxides, generated in situ upon treatment of the corresponding hydroximoyl chlorides $\mathbf{6 a - \mathbf { c } ^ { 4 3 }}$ with triethylamine, and alkenes 8, 10, and 12, respectively. A Wittig reaction performed on the known 7-tert-butoxycarbonyl-7-aza-byciclo[2.2.1]heptan-2-one $7^{44}$ afforded dipolarophile 8, whereas 7-tert-butoxycarbonyl-7-aza-byciclo[2.2.1] hept-2-ene $\mathbf{1 0}^{28}$ and 1-tert-butoxycarbonyl- $\Delta^{3}$-pyrroline $12^{45}$ were prepared following published procedures.

As expected, pyridinenitrile oxides attack the less hindered face of bicyclic olefin $\mathbf{1 0}$ yielding exclusively the exo-cycloadducts 11a-c. According to the literature, ${ }^{46-48}$ the observed syn facial selectivity is dictated by the anti pyramidalization of the olefinic hydrogens in the dipolarophile. The structural assignment to adducts 11a-c was unequivocally established by ${ }^{1} \mathrm{H}-\mathrm{NMR}$ spectroscopy, since the absence of vicinal coupling constants between protons $\mathrm{H}-1$ and $\mathrm{H}-2$ as well as between protons $\mathrm{H}-3$ and $\mathrm{H}-4$ (Scheme 1) is a clear indication of their exo configuration. ${ }^{49,50}$ By taking into account the outcome of reactions carried out on olefins structurally related to $\mathbf{8},{ }^{51,52}$ we assigned the exo configuration even to spirocyclic intermediates 9a-c, which were the only isomers isolated in each cycloaddition step. Finally, the pericyclic reaction of pyridinenitrile oxides with olefin 12 yielded bicyclic cycloadducts 13a-c. Treatment of cycloadducts 9a-c, 11a-c, and 13a-c with trifluoroacetic acid provided the desired epibatidine analogues as the free bases 3a-c, 4a-c, and 5a-c, respectively. The latter compounds were converted into the corresponding fumarates by treatment with fumaric acid in methanol and the salts obtained were submitted to biological testing. 


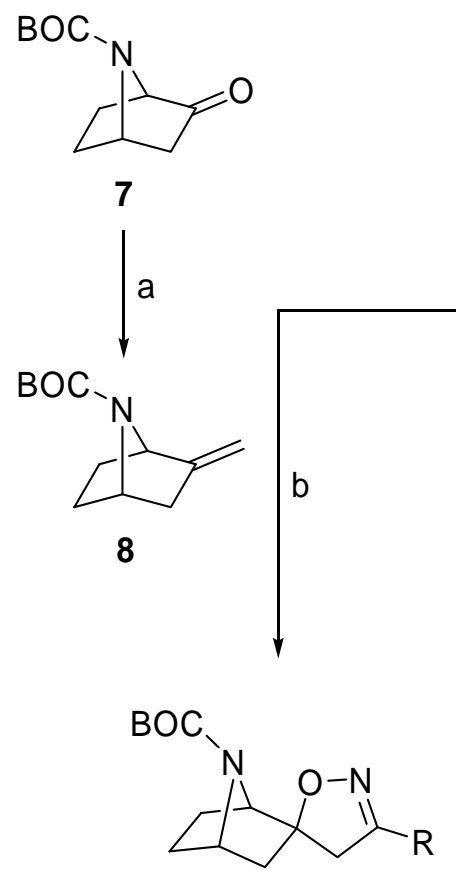

9a-c

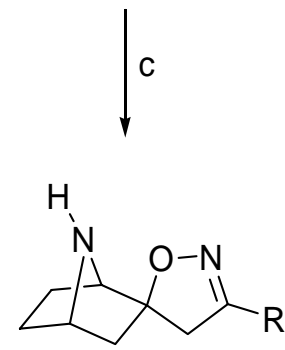

3a-c

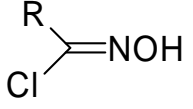

6a-c

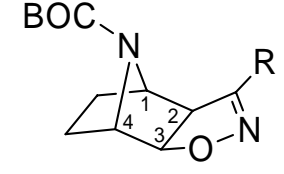

11a-c
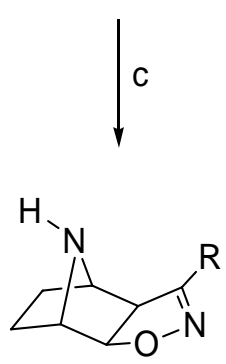

4a-c

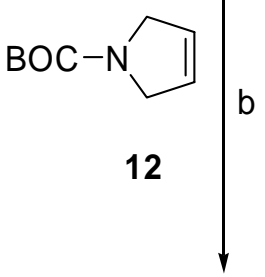<smiles>[R]C1=NOC2CN(C(=O)O)CC12</smiles>

13a-c<smiles>[R]C1=NOC2CNCC12</smiles>

5a-c<smiles>[R]#Cc1ccccn1</smiles><smiles>[R]#Cc1cccnc1</smiles><smiles>[CH]=Cc1ccncc1</smiles>

Scheme 1. a: $\mathrm{Ph}_{3} \mathrm{P}=\mathrm{CH}_{2}, \mathrm{Et}_{2} \mathrm{O}$; b: $\left(\mathrm{C}_{2} \mathrm{H}_{5}\right)_{3} \mathrm{~N}, \mathrm{CH}_{3} \mathrm{CN}, 60^{\circ} \mathrm{C}$; : $\mathrm{CF}_{3} \mathrm{COOH}, \mathrm{CH}_{2} \mathrm{Cl}_{2}$.

The fumarates of the target compounds 3a-c, 4a-c, and 5a-c were assessed for their binding affinity to $\alpha 4 \beta 2$ and $\alpha 7$ rat nicotinic receptor subtypes using $\left[{ }^{3} \mathrm{H}\right]$-epibatidine and $\left[{ }^{125} \mathrm{I}\right]-\alpha-$ bungarotoxin as radioligands, respectively. The $K_{\mathrm{i}}$ values were calculated from the competition curves by means of the LIGAND program. ${ }^{53}$ On the whole, the insertion of the $\Delta^{2}$-isoxazoline moiety between the azanorbornane system and the pyridine ring greatly reduced or abolished the binding affinity for the $\alpha 4 \beta 2 \mathrm{nAChR}$ subtype, since the $K_{\mathrm{i}}$ value of the reference radioligand falls within the 20-40 pM concentration range. Among the studied compounds, only derivative $5 \mathbf{b}\left(K_{\mathrm{i}}\right.$ $=72 \mu \mathrm{M})$ and the fused analogues $4 \mathrm{~b}\left(K_{\mathrm{i}}=86 \mu \mathrm{M}\right)$ and $4 \mathrm{c}\left(K_{\mathrm{i}}=68 \mu \mathrm{M}\right)$, which are characterized by the pyridine nitrogen in position 3 ' and 4' respectively, retained a residual and comparable 
affinity for the $\alpha 4 \beta 2$ nAChRs. Conversely, the two spirocyclic analogues $3 \mathbf{b}\left(K_{\mathrm{i}}=41 \mu \mathrm{M}\right)$ and $3 \mathbf{c}$ $\left(K_{\mathrm{i}}=28 \mu \mathrm{M}\right)$, in which the pyridine nitrogen atoms are located in position 3' and 4' respectively, showed the highest affinity for the $\alpha 7 \mathrm{nAChR}$ subtype, thus behaving quite similarly to the fused analogue $\mathbf{4 b}(\mathrm{Ki}=32 \mu \mathrm{M})$. In addition, derivative $3 \mathbf{c}$ evidenced a slight degree of selectivity for $\alpha 7$ over $\alpha 4 \beta 2$ receptor subtypes ( $K_{\mathrm{i}}$ values of 28 vs $400 \mu \mathrm{M}$, respectively).

The above discussed results on the group of novel epibatidine-related derivatives will be examined by taking into account both the ligand-based pharmacophore models reported in the literature and a recently proposed molecular model of the $\alpha 4 \beta 2$ receptor subtype. ${ }^{54}$

In conclusion, homologation of the structure of epibatidine, a prototype $\alpha 4 \beta 2$ selective agonist of nAChRs, led to the appearance of an unexpected, non negligible affinity for the $\alpha 7$ receptors. Moreover, among the compounds under study, the spirocyclic derivative 3c showed a degree of $\alpha 7$ vs $\alpha 4 \beta 2$ selectivity, a result which could be exploited in designing novel selective agonists of this nAChR subtype.

\section{Acknowledgments}

We are indebted to Dr. Cecilia Gotti and Prof. Francesco Clementi, Dipartimento di Farmacologia, Chemioterapia e Tossicologia Medica, Università di Milano, for the biological tests. This research was financially supported by MIUR, FIRB research project 2003 (RBNE03FH5Y_002).

\section{References}

1. Galzi, J.-L.; Changeux, J. P. Curr. Opin. Struct. Biol. 1994, 4, 554.

2. La Novère, N.; Changeux, J. P. J. Mol. Evol. 1995, 40, 155.

3. Dajas-Bailador, F.; Wonnacott, S. Trends Pharmacol. Sci. 2004, 25, 317.

4. Fenster, C. P.; Rains, M. F.; Noerager, B.; Quick, M. W.; Lester, R. A. J. J. Neurosci. 1997, $17,5747$.

5. Nai, Q.; McIntosh, J. M.; Margiotta, J. F. Mol. Pharmacol. 2003, 63, 311.

6. Gotti, C.; Clementi, F. Prog. Neurobiol. 2004, 74, 363.

7. Jensen, A. A.; Frølund, B.; Liljefors, T.; Krogsgaard-Larsen, P. J. Med. Chem. 2005, 48, 4705.

8. Abreo, M. A.; Lin, N.-H.; Garvey, D. S.; Gunn, D. E.; Hettinger, A.-M.; Wasicak, J. T.; Pavlik, P. A.; Martin, Y. C.; Donnelly-Roberts, D. L.; Anderson, D. J.; Sullivan, J. P.; Williams, M.; Arneric, S. P.; Holladay, M. W. J. Med. Chem. 1996, 39, 817.

9. Holladay, M. W.; Wasicak, J. T.; Lin, N.-H.; He, Y.; Ryther, K. B.; Bannon, A. W.; Buckley, M. J.; Kim, D. J. B.; Decker, M. W.; Anderson, D. J.; Campbell, J. E.; 
Kuntzweiler, T. A.; Donnelly-Roberts, D. L.; Piattoni-Kaplan, M.; Briggs, C. A.; Williams, M.; Arneric, S. P. J. Med. Chem. 1998, 41, 407.

10. Lindström, J. Mol. Neurobiol. 1997, 15, 193.

11. Paterson, D.; Nordberg, A. Progr. Neurobiol. 2000, 61, 75.

12. Lloyd, G. K.; Williams, M. J. Pharmacol Exp. Ther. 2000, 292, 461.

13. Holladay, M. W.; Dart, M. J.; Lynch, J. K. J. Med. Chem. 1997, 40, 4169.

14. Glennon, R. A.; Dukat, M. Pharm. Acta Helv. 2000, 74, 103.

15. Holladay, M. W.; Cosford, N. D. P.; McDonald, I. A. In Neuronal Nicotinic Receptors: Pharmacology and Therapeutic Opportunities; Arneric, S. P., Brioni, J. D., Eds; Wiley-Liss: New York, 1999; pp 253-270.

16. Tønder, J. E.; Olesen, P. H. Curr. Med. Chem. 2001, 8, 651.

17. Glennon, R. A.; Dukat, M. Bioorg. Med. Chem. Lett. 2004, 14, 1841.

18. Schmitt, J. D. Curr. Med. Chem. 2000, 7, 749.

19. Spande, T. F.; Garraffo, H. M.; Edwards, M. W.; Yeh, H. J. C.; Pannell, L.; Daly, J. W. J. Am. Chem. Soc. 1992, 114, 3475.

20. Meyer, M. D.; Decker, M. W.; Rueter, L. E.; Anderson, D. J.; Dart, M. J.; Kim, K. H.; Sullivan, J. P.; Williams, M. Eur. J. Pharmacol. 2000, 393, 171.

21. Daly, J. W.; Garraffo, H. M.; Spande, T. F.; Decker, M. W.; Sullivan, J. P.; Williams, M. Nat. Prod. Rep. 2000, 17, 131.

22. Daly, J. W. J. Med. Chem. 2003, 46, 445.

23. Li, T. C.; Qian, C. G.; Eckman, J.; Huang, D. F.; Shen, T. Y. Bioorg. Med. Chem. Lett. 1993, 3, 2759.

24. Sullivan, J. P.; Bannon A. W. CNS Drug Rev. 1996, 2, 21.

25. Gerzanich, V.; Peng, X.; Wang, F.; Wells, G.; Anand, R.; Fletcher, S.; Lindstrom, J. Mol. Pharmacol. 1995, 48, 774.

26. Sullivan, J. P.; Decker, M. W.; Brioni, J. D.; Donnelly-Roberts, D. L.; Anderson, D. A.; Bannon A. W.; Kang, C. H.; Adams, P.; Piattoni-Kaplan, M.; Buckley, M. J.; Gopalakrishnan, M.; Williams, M.; Arneric, S. P. J. Pharmacol. Exp. Ther. 1994, $271,624$.

27. Carroll, F. I.; Lee, J. R.; Navarro, H. A.; Brieaddy, L. E.; Abraham, P.; Damaj, M. I.; Martin, B. R. J. Med. Chem. 2001, 44, 4039.

28. Carroll, F. I.; Liang, F.; Navarro, H. A.; Brieaddy, L. E.; Abraham, P.; Damaj, M. I.; Martin, B. R. J. Med. Chem. 2001, 44, 2229.

29. Carroll, F. I.; Lee, J. R.; Navarro, H. A.; Ma, W.; Brieaddy, L. E.; Abraham, P.; Damaj, M. I.; Martin, B. R. J. Med. Chem. 2002, 45, 4755.

30. Wei, Z.-L.; Xiao, Y.; George, C.; Kellar, K. J.; Kozikowski, A. P. Org. Biomol. Chem. 2003, 1,3878 .

31. Sharples, C. G. V.; Karig, G.; Simpson, G. L.; Spencer, J. A.; Wright, E.; Millar, N. S.; Wonnacott, S.; Gallagher, T. J. Med. Chem. 2002, 45, 3235.

32. Gohlke, H.; Gündisch, D.; Schwarz, S.; Seitz, G.; Tilotta, M. C.; Wegge, T. J. Med. Chem. 2002, 45, 1064. 
33. Gohlke, H.; Schwarz, S.; Gündisch, D.; Tilotta, M. C.; Weber, A.; Wegge, T.; Seitz, G.; J. Med. Chem. 2003, 46, 2031.

34. Horti, A. G.; Scheffel, U.; Kimes, A. S.; Musachio, J. L.; Ravert, H. T.; Mathews, W. B.; Zhan, Y; Finley, P. A.; London, E. D.; Dannals, R. F. J. Med. Chem. 1998, 41, 4199.

35. Cox, C. D.; Malpass, J. R.; Gordon, J.; Rosen, A. J. Chem. Soc., Perkin Trans. 1 2001, 2372.

36. Romanelli, M. N.; Gualtieri, F. Med. Chem. Rev. 2003, 23, 393.

37. Badio, B.; Shi, D.; Garraffo, M.; Daly, J. W. Drug Dev. Res. 1995, 36, 46.

38. Damaj, M. I.; Glassco, W.; Dukat, M.; May, E. L.; Glennon, R. A.; Martin, B. R. Drug Dev. Res. 1996, 38, 177.

39. Conti, P.; De Amici, M.; Joppolo di Ventimiglia, S.; Bryan Stensbøl, T.; Madsen, U.; Bräuner-Osborne, H.; Russo, E.; De Sarro, G.; Bruno, G.; De Micheli, C. J. Med. Chem. 2003, 46, 3102.

40. Funicello, M.; Conti, P.; De Amici, M.; De Micheli, C.; Mennini, T.; Gobbi, M. Mol. Pharmacol. 2004, 66, 522.

41. Roda, G.; Conti, P.; De Amici, M.; He, J.; Polavarapu, P. L.; De Micheli, C. Tetrahedron: Asymmetry 2004, 15, 3079.

42. Conti, P.; De Amici, M.; Grazioso, G.; Roda, G.; Barberis Negra, F. F.; Nielsen, B.; Bryan Stensbøl, T.; Madsen, U.; Bräuner-Osborne, H.; Frydenvang, K.; De Sarro, G.; Toma, L.; De Micheli, C. J. Med. Chem. 2004, 47, 6740.

43. Kanemasa, S.; Matsuda, H.; Kamimura, A.; Kakinami, T. Tetrahedron 2000, 56, 1057.

44. Zhang, C.; Trudell, M. L. J. Org. Chem. 1996, 61, 7189.

45. Conti, P.; Dallanoce, C.; De Amici, M.; De Micheli, C.; Fruttero, R. Tetrahedron 1999, 55, 5623, and references cited therein.

46. De Micheli, C.; Gandolfi, R.; Oberti, R. J. Org. Chem. 1980, 45, 1209.

47. Caramella, P.; Grünanger, P. In 1,3-Dipolar Cycloaddition Chemistry, Padwa, A., Ed.; Wiley \& Sons, Inc., 1984, Vol. 3, pp 291-392.

48. Gandolfi, R.; Tonoletti, G.; Rastelli, A.; Bagatti, M. J. Org. Chem. 1993, 58, 6038.

49. Baker, R. J.; Chiu, S.; Klein, C.; Timberlake, J. W.; Trefonas, L. M.; Majesté, R. J. Org. Chem. 1980, 45, 482.

50. Dal Bo, L.; De Amici, M.; De Micheli, C.; Gandolfi, R.; Houk, K. N. Tetrahedron Lett. 1989, 30, 807.

51. Curran, D. P. J. Am. Chem. Soc. 1983, 105, 5826.

52. Brown, H. C.; Hammar, W. J.; Kawakami, J. H.; Rothberg, I.; Vander Jagt, D. L. J. Am. Chem. Soc. 1967, 89, 6381.

53. Munson, P. J.; Rodbard, D. Anal. Biochem. 1980, 107, 220.

54. Bisson, W. H.; Scapozza, L.; Westera, G.; Mu, L.; Schubiger, P. A. J. Med. Chem. 2005, 48, 5123. 